\title{
Pendekatan Humanis-Relegius pada Pendidikan Kristen sebagai Pembentukan Karakter Generasi Milenial
}

\author{
Petrus Marija ${ }^{1}$, Yudhi Kawangung ${ }^{2}$, Munatar Kause ${ }^{3}$ \\ ${ }^{1,2,3}$ Sekolah Tinggi Agama Kristen Teruna Bhakti, Yogayakarta \\ kristenbimas@yahoo.com ${ }^{1}$,ykawangung06gmail.com ${ }^{2}$, munatarmoses@gmail.com ${ }^{3}$
}

\begin{abstract}
Prior to basic education with an age range of 6 or 7 , and 8 or 9 years was a vulnerable period of cognitive, psychological, and emotional development. Children need education that can form good character and can reflect Christian values in their lives. The shift in the pattern of parental education as the first educational environment due to busy parents allows the lack of inculcation of character in the family environment. Schools become the foundation of hope for the formation of children's character in preparing generations in the millennial era. In the education process, indicators of success in learning methods are students enthusiastic about the lesson, happy, a change in thinking and attitudes of the learner's own will. Humans have a tendency for self-actualization because humans move forward to perfection or potential. Each individual has the creative ability to solve the problem. Religious humanist education contains two educational concepts that we want to integrate, namely humanist education and religious education. Integrating these two educational concepts with the aim of being able to build an education system that can shape the character of millennial generation through Christian Education. This type of research is an intrinsic case study (Intrinsic case study). Researchers focus on one particular object and are appointed as a case for in-depth study. so as to discover the reality behind the phenomenon. Based on the results of the analysis it is known that religious humanist education in Christian education has linear compounds, so the formation of the character of children, especially in this millennium era will be very tested when the religious humanist approach to Christian education can be actually carried out by educators and or educational institutions (Christian).
\end{abstract}

Keywords: human - religious; character building; Christian Education

\begin{abstract}
Abstrak: Sebermula pendidikan dasar dengan rentang usia 6 atau 7, dan 8 atau 9 tahun adalah masa rentan perkembangan kognisi, psikis, maupun emosional. Anak membutuhkan pendidikan yang dapat membentuk karakter yang baik dan dapat mencerminkan nilai-nilai kekristenan dalam kehidupannya. Pergeseran pola pendidikan orang tua sebagai lingkungan pendidikan pertama dikarenakan kesibukan orang tua memungkinkan minimnya penanaman karakter di lingkungan keluarga. Sekolah menjadi tumpuan harapan untuk pembentukan karakter anak dalam mempersiapkan generasi di era milenial. Dalam proses pendidikan, indikator keberhasilan pada metode pembelajaran adalah peserta didik antusias terhadap pelajaran, gembira, terjadinya perubahan berpikir dan sikap atas kemauan pembelajar sendiri. Manusia memiliki kecenderungan untuk aktualisasi diri karena manusia bergerak maju untuk kesempurnaan atau potensinya. Tiap individu memiliki kemampuan kreatif untuk menyelesaikan masalahnya. Pendidikan humanis relegius mengandung dua konsep pendidikan yang ingin diintergrasikan yaitu pendidikan humanis dan pendidikan relegius. Pengintegrasian dua konsep pendidikan ini dengan tujuan untuk dapat membangun sistem pendidikan yang dapat membentuk karakter generasi milenialmelalui Pendidikan Kristen. Jenis penelitian yang dilakukan adalah studi kasus intrinsik (intrinsic case study).Peneliti memusatkan perhatian pada satu objek tertentu dan diangkat sebagai kasus untuk dikaji secara mendalam. sehingga mampu menemukan realitas di balik fenomena. Berdasarkan hasil analisis diketahui bahwa pendidikan humanis religius pada pendidikan Kristen
\end{abstract}


memiliki senyawa yang linear, sehingga pembentukkan karakter anak khususnya di era milenium ini akan sangat teruji ketika pendekatan humanis relegius pada pendidikan Kristen bisa secara nyata dilakukan oleh pendidik dan atau lembaga pendidikan (kristiani).

Kata kunci: human-religious; Pendidikan Kristen; pembentukan Karakter

\section{Pendahuluan}

Tingkatan kelas di sekolah dasar dapat dibagi menjadi dua, yaitu kelas rendah dan kelas tinggi. Kelas rendah terdiri dari kelas satu, dua, dan tiga, sedangkan kelas-kelas tinggi terdiri dari kelas empat, lima, dan enam (Supandi, 1992: 44). Di Indonesia, rentang usia siswa SD, yaitu antara 6 atau 7 tahun sampai 12 tahun. Usia siswa pada kelompok kelas rendah, yaitu 6 atau 7 sampai 8 atau 9 tahun. Siswa yang berada pada kelompok ini termasuk dalam rentangan anak usia dini. Masa usia dini ini merupakan masa yang pendek tetapi sangat penting bagi kehidupan seseorang. Oleh karena itu, pada masa ini seluruh potensi yang dimiliki anak perlu didorong sehingga akan berkembang secara optimal dalam era milenium.

Pergeseran pola pengasuhan anak yang semula dipercayakan penuh pada keluarga ke lembaga-lembaga pendidikan bukan hanya menjadi fenomena masyarakat perkotaan namun sudah merambah pada keluarga-keluarga yang tinggal di pedesaan. Pada keluarga pedesaan seorang anak memungkinkan hanya tinggal dengan nenek karena orang tuanya harus merantau ke kota. Sekolah menjadi harapan satu-satunya bukan hanya mengembangkan kognisinya namun pembentukan karakter. Dalam UU No. 2 Tahun 1989 tentang sistem Pendidikan Nasional, dikemukakan bahwa pendidikan dasar diselenggarakan untuk mengembangkan sikap dan kemampuan serta memberikan pengetahuan dan keterampilan dasar yang diperlukan untuk hidup di masyarakat serta mempersiapkan peserta didik yang memenuhi persyaratan untuk mengikuti pendidikan menengah (pasal 13). Dengan demikian maka pada pendidikan dasar merupakan penanaman nilai-nilai dan pengetahuan yang bersifat fundamentalik yang nantinya akan membekali pada pendididikan lanjut bagi generasi milenium.

Praksis pendidikan di Indoesia terutama pada sekolah dasar lebih menekankan pada perkembangan kognitif sehingga kemampuan afektif dan psikomotor siswa terabaikan. Hal ini memungkinkan terjadinya praktik pendidikan yang tidak equality dan equity. Anak yang cerdas dan pandai cenderung mendapat perhatian guru dibandingkan anak yang dianggap pasif atau kurang memiliki kemampuan kognitif. Praksis pendidikan yang demikian memungkinkan siswa yang tidak mendapat perhatian penuh dari guru akan melakuan tindakan-tindakan yang dianggap guru menggangu proses belajar.

Pendidikan merupakan sarana penting dalam pengembangan manusia. Tujuan pendidikan adalah mengembangkan potensi yang ada dalam diri manusia; yakni intelektual, moral, artisik agar anak dapat berinteraksi dengan lingkungan secara kreatif. Implikasi penting bagi pendidikan bahwa pendidikan tidak hanya mengajarkan ilmu dan 
teknologi. Pendidikan berarti membantu pengembangan-pengembangan kompetensi di ketiga bidang yakni lingkungan, komunikasi, dan kritik. ${ }^{1}$

Lingkungan memiliki peran penting dalam membentuk kemandirian anak untuk bersosialisasi dengan lingkungannya. Lingkungan pada dasarnya merupakan tempat pendidikan bagi anak, namun anak harus dibantu untuk berada dalam lingkungan masyarakat karena masyarakat memiliki nilai-nilai yang harus dipahami oleh anak. Pengembangan pribadi anak akan membantu anak untuk beradaptasi dengan sosial kulturnya sehingga anak akan berkembang secara optimal dan potensi tersebut berguna untuk anak maupun lingkungannya pada era milenium.

Pengembangan kepribadian yang optimal akan memunculkan kepercayaan diri, dan kepercayaan diri akan dapat dikembangkan dalam kehidupan berdasarkan pengalaman belajar maka itulah hasil belajar yakni pembentukan aktualisasi diri. Hal ini dikemukakan oleh Rogers bahwa,

Self-concept and conditions of worth are linked together and are important. They are guidelines as to how people behave towards others because people value their opinion of themselves above their own. This affects their decision making and can result in them doing things to please others rather than satisfying their own needs. Conditions of worth reduce people's self-confidence, trust in their own feelings and can affect their potential towards self-actualisation. ${ }^{2}$

Carl Rogers adalah seorang humanis dan psikoterapis. Dia percaya jika seseorang mencapai self-actualisation mereka akan menjadi orang yang berfungsi sepenuhnya hidup "baik hidup." Dengan ini, berarti bahwa individu akan memiliki pandangan yang positif psikologis sehat, mempercayai perasaan mereka sendiri dan memiliki harmoni dalam hidup mereka antara diri dan pengalaman. Dapat diartikan bahwa proses pendidikan akan berhasil baik ketika pendidikan itu dapat membangun kepercayaan diri dan aktualisasi diri. Kepercayaan diri bukan hanya intelektual namun sikap dan pemahaman nilai-nila kehidupan. Pendidikan demikian merupakan pendidikan humanis.

The World Summit for Children di PBB pada tahun 1990 yang dihadiri oleh 70 kepala negara menunjukkan betapa kepedulian pemerintah sedunia untuk memperbaiki nasib anak-anak sebagai generasi milenium pada abad ke 21 melalui pendidikan. Usahausaha guna mengutamakan nilai-nilai kemanusiaan dalam pendidikan melahirkan kembali pendekatan pendidikan yang mementingkan pengembangan kreatifitas dalam kepribadian anak, inilah yang disebut gerakan humanisasi dalam proses pendidikan yang sedang popular di banyak negara (Tilaar, 1999).

Tokoh-tokoh pendidikan yang merekomendasikan pendidikan humanis, diantaranya Abraham H. Maslow tokoh psikologi humanistik. Karyanya di bidang pemenuhan kebutuhan berpengaruh pada upaya memahami motivasi manusia. Teorinya didasarkan

\footnotetext{
${ }^{1}$ M. Satrapratedja, SJ. Pendidikan sebagai Humanisasi (Yogyakarta: Universitas Sanata Dharma, 2001), 6

${ }^{2}$ Carls Rogers, Antara Engkau dan Aku (Jakarta: PT. Gramedia, 1987)
} 
pada asumsi bahwa dalam diri manusia terdapat dorongan positif untuk tumbuh dan kekuatan-kekuatan yang melawan atau menghalangi pertumbuhan (Rumini dkk, 1993). Maslow berpendapat, bahwa manusia memiliki hierarki kebutuhan yang dimulai dari kebutuhan jasmaniah yang paling asasi hingga kebutuhan tertinggi yakni kebutuhan estetis. Apabila kebutuhan ini terpuaskan, maka munculah kebutuhan keamanan seperti kebutuhan kesehatan dan kebutuhan terhindar dari bahaya dan bencana. Berikutnya adalah kebutuhan untuk memiliki dan cinta kasih, seperti dorongan untuk memiliki kawan dan berkeluarga, kebutuhan untuk menjadi anggota kelompok, dan sebagainya.

Ketidakmampuan memenuhi kebutuhan ini dapat mendorong seseorang berbuat lain untuk memperoleh pengakuan dan perhatian, misalnya dia menggunakan prestasi sebagai pengganti cinta kasih. Sedangkan kebutuhan harga diri, yaitu kebutuhan untuk dihargai, dihormati, dan dipercaya oleh orang lain. Apabila seseorang telah dapat memenuhi semua kebutuhan yang tingkatannya lebih rendah tadi, maka motivasi lalu diarahkan kepada terpenuhinya kebutuhan aktualisasi diri, yaitu kebutuhan untuk mengembangkan potensi atau bakat dan kecenderungan tertentu. Bagaimana cara aktualisasi diri ini tampil, tidaklah sama pada setiap orang. Sesudah kebutuhan ini, muncul kebutuhan untuk tahu dan mengerti, yakni dorongan untuk mencari tahu, memperoleh ilmu dan pemahaman. Sesudahnya, Maslow berpendapat adanya kebutuhan estetis, yakni dorongan keindahan, dalam arti kebutuhan akan keteraturan, kesimetrisan dan kelengkapan.

Rogers mengemukakan gagasan-gagasannya yang berpengaruh terhadap pikiran dan praktek psikologi di semua bidang, baik klinis, terutama di bidang pendidikan. Rogers mengutarakan pendapat tentang prinsip-prinsip belajar yang humanistik, yang meliputi hasrat untuk belajar, belajar yang berarti, belajar tanpa ancaman, belajar atas inisiatif sendiri, dan belajar untuk perubahan (Rumini dkk, 1993). Adapun penjelasan konsep masing-masing prinsip tersebut adalah sebagai berikut : a). Hasrat untuk Belajar. Manusia mempunyai hasrat alami untuk belajar. Hal ini terbukti dengan tingginya rasa ingin tahu anak apabila diberi kesempatan untuk mengeksplorasi lingkungan. Dorongan ingin tahu untuk belajar ini merupakan asumsi dasar pendidikan humanistik. Di dalam kelas yang humanistik anak-anak diberi kesempatan dan kebebasan untuk memuaskan dorongan ingin tahunya, untuk memenuhi minatnya dan untuk menemukan apa yang penting dan berarti tentang dunia di sekitarnya. b). Belajar yang Berarti. Yang dimaksud dengan yang memiliki arti atau makna apabila apa yang dipelajari relevan dengan kebutuhan siswa.

Artinya, siswa akan belajar dengan cepat apabila yang dipelajari mempunyai arti baginya. c). Belajar tanpa ancaman akan mudah dilakukan dan hasilnya dapat disimpan dengan baik terutama ketika belajar berlangsung dalam lingkungan yang bebas ancaman. Proses belajar akan berjalan lancar manakala siswa dapat menguji kemampuannya, sehingga dapat mencoba pengalaman-pengalaman baru atau membuat kesalahankesalahan tanpa mendapat kecaman yang dapat menimbulkan perasan tidak nyaman atau traumatik. d). Belajar atas Inisiatif Sendiri. Belajar akan paling bermakna apabila hal itu 
dilakukan atas inisiatif sendiri dan melibatkan perasaan dan pikiran siswa. Ketika siswa mampu memilih arah belajarnya sendiri akan memberikan motivasi dan mengulurkan kesempatan kepada siswa untuk "belajar bagaimana caranya belajar" (to learn how to learn). Tidaklah perlu diragukan bahwa menguasai bahan pelajaran itu penting, akan tetapi tidak lebih penting daripada memperoleh kecakapan untuk mencari sumber, merumuskan masalah, menguji hipotesis atau asumsi, dan menilai hasil belajar. Belajar atas inisiatif sendiri juga mengajar siswa menjadi bebas, tidak bergantung, dan percaya pada diri sendiri. Dengan belajar atas inisiatif sendiri, maka siswa memiliki kesempatan untuk mempertimbangkan dalam membuat keputusan, menentukan pilihan serta melakukan penilaian. Siswa akan menjadi lebih bergantung pada dirinya sendiri dan kurang bersandar pada penilaian orang lain.

Keputusan-keputusan yang diambil anak merupakan keputusan nilai yang berlaku dalam lingkungan masyarakat terutama tata nilai keagamaan. Oleh karena itu maka, Sodiq A. Kuntoro, 2008 dalam Skesta Pendidikan Humanis Relegius mengemukakan bahwa pendidikan humanis relegius mengandung dua konsep pendidikan yang ingin dintergrasikan yaitu pendidikan humanis dan pendidikan relegius. Pengintegrasian dua konsep pendidikan ini dengan tujuan untuk dapat membangun sistem pendidikan yang dapat mengintegrasikan dari keduanya atau mengurangi kelemahannya. Pendidikan humanis menekankan aspek kemerdekaan individu diintegrasikan dengan pendidikan relegius agar dapat membangun kehidupan individu (sosial) yang memiliki kemerdekaan tetapi tidak meninggalkan (sekuler) dan nilai-nilai keagamaan yang diikuti masyarakatnya atau menolak nilai Tuhanan (ateisme).

Pendidikan Kristen mengandung filosofi bahwa pendidikan Kristiani berpusat pada Tuhan. Dalam Amsal 1:7 dikemukakan takut akan Tuhan adalah permulaan pengetahuan, dengan filsafat pengajaran ini maka anak dapat membangun karakter yang baik karena muara pengetahuan adalah Tuhan (Kristus). Dalam proses pendidikan, indikator keberhasilan pada metode pembelajaran adalah peserta didik antusias terhadap pelajaran, gembira, terjadinya perubahan berpikir dan sikap atas kemauan siswa sendiri.

Pendidikan yang dilaksanakan dengan menyenangkan akan dapat menanamkan nilainilai pembentukan karakter siswa. Menurut Ratna Megawangi ada banyak kualitas karakter yang harus dikembangkan, namun untuk memudahkan pelaksanaan, pengembangkan konsep pendidikan 9 pilar karakter yang merupakan nilai-nilai luhur universal (lintas agama, budaya dan suku). Diharapkan melalui internalisasi 9 pilar karakter ini, para siswa akan menjadi manusia yang cinta damai, tanggung jawab, jujur, dan serangkaian akhlak mulia lainnya. Ada pun nilai-nilai 9 pilar karakter terdiri dari.1). Cinta Tuhan dan alam semesta beserta isinya 2). Tanggung jawab, Kedisiplinan, dan Kemandirian 3). Kejujuran 4). Hormat dan Santun 5). Kasih Sayang, Kepedulian, dan Kerjasama 6). Percaya Diri, Kreatif, Kerja Keras, dan Pantang Menyerah 7). Keadilan dan Kepemimpinan 8). Baik dan Rendah Hati 9). Toleransi, Cinta Damai, dan Persatuan. 
Metode penanaman 9 pilar karakter tersebut dilakukan secara eksplisit dan sistematis, yaitu dengan knowing the good, reasoning the good, feeling the good, dan acting the good ternyata telah berhasil membangun karakter anak. Dengan knowing the good anak terbiasa berpikir hanya yang baik-baik saja. Reasoning the good juga perlu dilakukan supaya anak tahu mengapa dia harus berbuat baik. Misalnya kenapa anak harus jujur, apa akibatnya kalau anak jujur, dan sebagainya. Jadi, anak tidak hanya menghafal kebaikan tetapi juga tahu alasannya. Dan juga dengan feeling the good, kita membangun perasaan anak akan kebaikan. Anak-anak diharapkan mencintai kebaikan. Lalu, dalam acting the good, anak mempraktekkan kebaikan. Jika anak terbiasa melakukan knowing, reasoning, feeling, dan acting the good lama kelamaan anak akan terbentuk karakternya. ${ }^{3}$ Sedangkan pendidikan yang memanusiakan akan: a) membantu siswa mengembangkan gambaran diri yang positif sarat rasa harga diri, bahwa dirinya layak, penting, diterima, dan mampu. b) Mengembangkan intelegensi emosional dan kemampuannya untuk berempati, ugahari, dan penguasaan diri. c) Mengembangkan keutamaan intelektual, kemampuan kritis dan reflektif, penilaian yang sehat, imaginatif kreatif, dan kepekaan akan nilai. ${ }^{4}$

Proses belajar mengajar sebagai hubungan manusiawi mempunyai implikasi yang luas bagi hubungan pendidik dan peserta didik, peran masing-masing, metode mengajar dan belajar, perencanaan kurikulum, pembinaan kelompok, cara komunikasi dan lain-lain. Kecenderungan sistem pendidikan di Indonesia dengan gaya bank dalam arti anak didik dipandang sebagai obyek yang harus diberikan materi hafalan tanpa pemahaman, sehingga perlu adanya perumusan kembali dengan mengubah sistem pendidikan yang lebih mementingkan subjek dan memanusiakan subjek dan bukan kebutuhan guru ataupun pemerintah (Paulo Freire, 1988:14). Pendidikan diharapkan mampu menjadikan siswa sebagai pelaku pendidikan sehingga mampu membentuk pribadi yang unggul, pribadi utuh dan pribadi yang memiliki ketangguhan dan kesiapan dalam menghadapi permasalahanpermasalahan dan memiliki nilai-nilai dan kritis terhadap ber $\neg$ bagai permasalahan. Untuk itu maka pendidikan humani-s relegius merupakan salah satu alternatif dalam perubahan sistem pendidikan agar mampu menjawab perubahan-perubahan sosial.

Arthur W. Combs pun menawarkan sebuah konsep baru tentang pengembangan potensi manusia yang bernuansa humanistik, dan ini merupakan suatu tantangan baru bagi para pendidik dalam menekankan pentingnya aktualisasi diri terhadap anak didik. Adapun rumusan masalahnya adalah sebagai berikut, pertama, bagaimanakah pendidikan humanis relegius diterapkan pada generasi milenium? Kedua, bagaimanakah nilai humanis relegius dapat membantu generasi milenium dapat mengaktualisasikan dirinya? Penelitian ini bertujuan untuk, mendeskripsikan pendidikan humanis relegius dalam pembentukan watak

${ }^{3}$ www.goodreads.com

${ }^{4}$ M. Sastrapratedja, "Humanisme sebagai Prinsip Pendidikan menurut Driyarkara", Makalah Ilmiah, Disampaikan dalam Konggres Pendidikan, Pengajaran, dan Kebudayaan Tahun 2012, Balai Senat UGM, 7-8 Mei 2012 
kristiani melalui Pendidikan Kristen. Menghasilkan kajian pemikiran pendidikan anak sehingga proses pendidikan anak sesuai dengan tujuan yang relevan dengan kebutuhan dan perkembangan anak di Indonesia. Menghasilkan kajian pemikiran pendidikan anak yang sesuai dengan sosial kultur keindonesiaan sehingga anak dapat memahami nilai-nilai karakter yang ada di masyarakat sebagai bagian masyarakat sehingga memberikan kontribusi positif dalam lingkungannya. Menghasilkan konsep pemikiran pendekatan humanisme relegius memungkinkan memberikan kontribusi bagi perkembangan pendidikan anak di Indonesia sehingga memberikan arah yang jelas pada standar pembelajaran anak.

Kajian pendidikan bagi generasi milenium didasarkan pada pendekatan Humanisme Relegius diharapkan akan memberikan masukan secara komprehensif pengajaran anak. Pendidik dapat mengenali kebutuhan anak sehingga dapat dengan tepat mengambil suatu tindakan yang dapat mengoptimalkan perkembangan anak. Pengoptimalan perkembangan anak didasarkan pada pemahaman pengasuhan dan pengajaran yang memperhatikan unsur filosofi, psikologi, bahkan sosial kultural anak yang nilai-nilai budaya Indonesia sehingga membentuk karakter yang baik yang mencerminkan manusia Indonesia.

Hasil penelitian ini diharapkan akan menemukan konsep Pendidikan Kristen yang telah memberi kontribusi pada pendidikan anak di Indonesia sehingga semua pendidikan dasar dapat menerapkannya. Pendidikan Kristen dapat menemukan format baku dalam strategi maupun metode pendidikan sehingga pembentukan karakter Kristiani dapat terwujud dalam kehidupan peserta didik yang bermanfaat bagi kehidupan pribadi, masyarakat dan negara.

Pada penelitian ini hal yang paling utama dan menjadi atensi khusus adalah pendidikan pembentukkan karakter oleh karena saat ini bangsa Indonesia terus bergulat dengan pembenahan pendidikan. Salah satu upaya yang dilakukan oleh berbagai pihak terutama dunia pendidikan yaitu dengan mencoba merombak kurikulum yang ada sehingga mendapatkan suatu formula yang tepat untuk memperbaiki bentuk pendidikan yang telah di gerus oleh perkembangan jaman dengan hadirnya berbagai macam teknologi. Perlu dicatat bahwa teknologi modern bukan hal yang negatif akan tetapi teknologi telah menyumbang jamaknya kerusakkan pendidikan walaupun demikian teknologi juga memberikan kontribusi dalam perkembangan pendidikan yang berbasis IPTEK (Ilmu Pengetahuan dan Teknologi).

Bila diamati dengan cermat moral dan etika telah mengalami degradasi dimana pendidikan yang diharapkan dapat mengurai persoalan tersebut justru terjebak hanya dalam tanggung jawab parsial. Pendidikan saat ini hanya mengedepankan aspek kognitif sehingga mengakibatkan anak-anak bangsa pintar bahkan sangat intelektual tetapi tidak memiliki empati terhadap sekitarnya dan tidak mampu melakukan keterampilan yang bermanfaat bagi orang lain. Anak-anak memiliki intelektual yang tinggi namun secara 
moral dan etika sangat rentan, konstruksi karakternya sangat lemah sehingga terkadang mereka menjadi pribadi yang arogan.

Berikutnya keutamaan penelitian disentralkan juga pada pendidikan humanisreligius, ini merupakan kajian baru yang ingin dikembangkan secara masif oleh peneliti dengan harapan mampu menjawab persolan yang ada. Pendidikan religius sebenarnya bukan hal yang baru karena salah satu kunci untuk membentuk karakter anak secara positif adalah dengan menggunakan pendekatan spiritualitas. Pendidikan keagamaan merupakan bagian penting dalam pembentukkan karakter anak oleh karena ada banyak kaidah-kaidah, petunjuk-petunjuk moral etis yang telah diinformasikan oleh pendidikan agamis baik dalam ajaran Islam, Katolik, Kristen, Hindu, Budha dan Konghu-Cu semua tanpa terkecuali memberikan kontribusi dalam keteladanan akhlak. Namun itu semua belum cukup untuk menjawab dan memberikan kontribusi yang besar dalam pembentukkan karakter anak.

Terakhir yang menjadi perhatian utama dalam riset ini adalah pengembangan ilmu pendidikan melalui humanis-religius yang diharapkan mampu memberikan kontribusi positif-aplikatif. Peneliti mengakui bahwa pendidikan humanis-religius merupakan kajian yang sangat berbasis moderat oleh karena pendekatan yang digunakan sangat relevan dalam kehidupan berbangsa dan bernegara dimana penekanan dan penegasan bersifat elegan sehingga menghasilkan anak-anak yang berkarakter, berkepribadian dan bermental manusia sejati seperti yang telah diwariskan oleh Tuhan Yesus Kristus.

\section{Metode Penelitian}

Jenis penelitian yang dilakukan adalah studi kasus intrinsik (intrinsic case study). Robert E.Stake mengemukakan bahwa jenis penelitian ini untuk mendapatkan pemahaman yang lebih baik dari kasus yang khusus, hal ini disebabkan karena seluruh kekhususan dan keluarbiasaan kasus itu sendiri menarik perhatian. Tujuannya bukan untuk membangun teori, meskipun pada waktu lain peneliti mungkin mengerjakan hal tersebut. ${ }^{5}$ Poerwandari (2005:108) juga mengemukakan bahwa studi kasus intrinsik dilakukan karena ketertarikan pada suatu kasus khusus. Penelitian dilakukan untuk memahami secara utuh kasus tersebut, tanpa harus menghasilkan suatu konsep atau teori. Pendekatan penelitian dengan studi kasus ini membuat peneliti dapat memperoleh pemahaman yang utuh dan terintegrasi mengenai keterkaitan antar berbagai fakta dan dimensi dari kasus tersebut.

Studi kasus diartikan sebagai metode atau strategi dalam penelitian untuk mengungkap kasus tertentu. Penelitian studi kasus memusatkan perhatian pada satu objek tertentu yang diangkat sebagai sebuah kasus untuk dikaji secara mendalam sehingga mampu menemukan realitas di balik fenomena. Dengan menggunakan penelitian studi kasus, peneliti berupaya mencari pemahaman mendalam mengenai suatu fenomena tertentu dan hasil penelitian tersebut memberikan gambaran luas serta mendalam. Fenomena

\footnotetext{
${ }^{5}$ Denzin. N. K. \& Lincoln. Y. S. Handbook of Qualitative Research (London: Sage, 2009), 301.
} 
pendekatan humanis relegius pada pendidikan Kristen akan membangun karakteristik Kristiani.

\section{Pembahasan}

\section{Pendidikan Humanis}

Pemikiran filsafat humanisme pertama-tama bertolak dari pengakuan terhadap manusia. Manusia adalah individu yang rasional sebagai nilai yang tertinggi dan sumber nilai terakhir. Manusia dianggap bukan sebagian dari alam yang statis tetapi sebagai mahluk yang kreatif. Bukankah manusia itu merupakan titik dari alam semesta? Manusia adalah sumber norma dan secara rasional dapat menguasai dan menyusun alam tanpa konsep yang transendental. Manusia adalah ukuran dari segala-segalanya seperti ungkapan Protagoras pada masa Yunani Kuno.

Apabila manusia adalah ukuran dari segala-galanya dan menghormati nilai-nilai manusia yang nyata, maka humanisme. Auguste Comte adalah seorang humanis yang sangat ekstrim. Manusia menjadi titik tolak dan ukuran dari segala sesuatu dan dengan demikian mengakui adanya keragaman manusia atau pluralisme. Dengan sendirinya absolutisme ditolak karena tidak mengakui pluralisme manusia. Humanisme dengan demikian melihat alam dan dunia sebagai dunia yang terbuka dan kebebasan manusia untuk menyusun dan mengaturnya. Individualisme menonjol dari kehidupan sosial yang statis pada Abad Pertengahan, karena diatur oleh nilai-nilai absolut berdasarkan agama. Humanisme merobek segala keterikatan yang menekan kebebasan umat manusia. Dari titik tolak inilah muncul alternatif-alternatif pemikiran baru yang mengorbitkan manusia sebagai penyandang nilai yang tertinggi. Kebebasan individu dan tanggung jawab serta melihat dunia yang memberikan berbagai pilihan telah mendorong manusia itu sebagai mahluk yang harus memikul tanggung jawab atas kebebasannya.

Dehumanisasi adalah bentuk ungkapan nyata dari proses aliensi dan dominasi, sedangkan pendidikan yang humanis adalah sebuah proyek utopia (dalam arti yang posisif) untuk kaum tertindas dan terjajah. Jelas keduanya mengimplikasikan sebuah aksi yang dilakukan oleh mereka sendiri dalam kehidupan sosial untuk melanggengkan status quo atau mengubah nama secara radikal.

Di sini ditegaskan lagi apa yang sebenarnya terjadi dan keterkaitan antara proses dehumanisasi dan pendidikan yang humanis. Sekali lagi, keduanya membutuhkan aksi sosial untuk menjaga atau memodifikasi realitas mereka masing-masing. Kita menekankan ini untuk membantah ilusi kaum ideali dan angan-angan pendidikan yang humanis yang tidak disertai dengan transformasi dunia yang tidak adil dan menindas; dan ini sangat penting. Ilusi semacam ini sebenarnya hanya melayani kepentingan pihak yang diuntungkan saja dan mengekspos ideologi yang menciptakan sindrom kemakmuran dengan cara meminta kaum tertindas untuk bersabar menunggu hari-hari yang lebih cerah.

Tidak ada dimensi humanistik dalam penindasan, juga tidak ada proses humanisasi dalam liberalisme yang kaku. Namun liberalisme tidak bisa menguasai kesadaran manusia, 
jika ia terisolasi dari dunia luar. Pembebasan hanya terjadi dalam sejarahnya masingmasing, ketika ia melibatkan sebuah kesadaran kritis atas hubungan implisit antara kesadaran sendiri dan dunia. Ini merupakan salah satu hal yang mendasar sebagai implikasi dari pendidikan yang humanis yang akan mengantarkan kita kepada ketidakmungkinan lain yang ditegaskan dalam banyak studi, yakni netralis pendidikan. Selain mengisyaratkan munculnya ancaman dehumanisasi, usaha ke arah pendidikan yang humanis tersebut juga mengimplikasikan praktik-praktik pendidikan yang berkebalikan. Sebagai dua hal yang saling bertentangan, proses humanisasi dan dehumanisasi yang menetapkan tugas-tugas pendidikan yang sangat antogonistik. Pendidik yang humanis dan liberal telah mereduksi dehumanisasi dan dengan demikian antara kesadaran manusia dan dunia atau antara manusia dan dunianya.

Pada dasarnya, salah satu perbedaan utama antara pendidikan sebagai sebuah kewajiban humanis dan liberal, disatu sisi dengan dominasi dan dehumanisasi, di sisi yang lain adalah bahwa dehumanisasi meruapakan proses pemindahan ilmu pengetahuan sedangkan dehumanisasi merupakan proses pemberdayaan masyarakat melalui ilmu pengetahuan. Memang keduanya saling berlawanan yang otomatis juga menciptakan prosedur yang juga berlainan yang berkisar pada hubungan antara kesadaran manusia dan dunia. Dalam hubungan dengan kesadaran manusia dan dunia, pendidikan yang dilihat sebagai bentuk dominasi menganggap kedasaran manusia semata-mata merupakan wadah kosong yang harus diisi; sedangkan pendidikan sebagai sebuah proses pembebasan dan humanisasi memandang kesadaran itu sebagai suatu 'hasrat' (intention) terhadap dunia.

Dengan mengasumsikan pendidikan sebagai proses dominasi, orang yang menguasai ilmu pengetahuan justru meniadakan prinsip kesadaran aktif. Pendidikan ini menjalankan praktik-praktik yang digunakan orang untuk 'menjinakkan' kesadaran manusia, mentransformasikan ke dalam sebuah wadah kosong. Pendidikan budaya dalam dominasi ini diarahkan pada situasi di mana guru merupakan satu-satunya orang yang mengetahui dan mengajarkan ilmu pengetahuan kepada peserta didik sebagai orang yang tidak tahu apa-apa.

Dalam pendidikan yang humanis, ketika seseorang sudah menindaklanjuti rasa keingintahuan sebagai peneliti dan peyelidik, dan ketika telah berhasil mengakses ilmu pengetahuan, maka seseorang tersebut dapat mengetahui dengan pasti kapasitas dalam mendapat mengenali atau menciptakan ilmu pengetahuan baru. Selain itu, juga dapat mengindentifikasikan dan mengapresiasi apa yang masih belum diketahui. Jika tidak demikian, maka tidak ada kesadaran untuk menciptakan ilmu pengetahuan baru, sehingga tidak memungkinkan adanya perkembangan ilmu pengetahuan yang baru, karena mengetahui sesuatu adalah sebuah proses. Ilmu pengetahuan yang saat ini dipelajari banyak orang yang dulunya juga berasal dari semangat seperti yang kemudian melahirkan ilmu pengetahuan baru yang berhubungan dan merupakan kelanjutan dari ilmu pengetahuan sebelumnya. 
Pendidikan dan aksi-aksi budaya yang membebaskan bukanlah proses transformasi yang 'mengasingkan' ilmu pengetahuan, namun merupakan proses yang otentik untuk mencari ilmu pengetahuan guna memenuhi hasrat keinginan peserta didik dan guru dan kesadaran untuk menciptakan ilmu pengetahuan baru. Ini sebagai sebuah konsekuensi setelah mereka memahami ilmu pengetahuan yang ada sekarang ini. Walaupun mengklaim pendidikan sebagai praktik pembebasan yang ditujukan untuk mengkaji ilmu pengetahuan sekarang dalam rangka mencari ilmu pengetahuan baru, hal ini tidak akan tercapai jika perlakuan oleh pendidik yang dominatif. Guru yang humanis harus tepat dalam memahami hubungan antara kesadaran manusia dan dunia, dan antara manusia dan dunia. Bentuk pendidikan yang membebaskan melalui difinisi ini menawarkan suatu 'arkeologi kedasaran'. Dengan usahanya sendiri, orang bisa menghidupkan kembali proses alamiah di mana kesadaran timbul dari kemampuan mempersepsi diri (Freire, 2007:192 dengan penyesuaian). Pendidikan humanis memiliki pandangan tentang pendidikan sebagai berikut:

Tujuan pendidikan dan proses pendidikan berasal dari anak. Oleh karenanya kurikulum dan tujuan pendidikan menyesuaikan kebutuhan, minat dan prakarsa anak. Siswa adalah aktif bukan pasif. Anak memiliki keinginan belajar dan melakukan aktivitas belajar apabila mereka tidak difrustasikan oleh orang dewasa. Peran guru adalah penasihat pembimbing, teman belajar bukan penguasa kelas. Sekolah sebagai bentuk dari masyarakat kecil. Aktivitas belajar harus fokus pada pemecahan masalah bukan sekadar mengajarkan mata pelajaran. Iklim sekolah harus demokratis dan kooperatif. Karena kehidupan di masyarakat selalu hidup bersama dengan orang lain, maka setiap orang harus mampu membangun kooperasi dengan orang lain (Sodiq A. Kuntoro, 1988).

\section{Pendekatan Humanis Relegius}

Berdasarkan teori psikologi Maslow salah satu ciri manusia ialah memiliki "kebutuhan". Kebutuhan ini menjadi daya pendorong untuk berbuat yang disebut motivasi. Kebutuhan atau motivasi tersusun secara hirarkis. Apabila kebutuhan yang lebih rendah terpenuhi maka akan muncul yang lebih tinggi sampai akhirnya mencapai kebutuhan tertinggi yaitu aktualisasi diri. Kebutuhan akan aktualisasi diri adalah dorongan untuk mewujudkan potensi yang mungkin dalam diri manusia; perbaikan diri, perkembangan diri, perwujudan bakat, idak merupakan gerak yang otomatis. ${ }^{6}$

Demikian juga dengan Freire pembebasan merupakan humanisasi, teori ini menguatkan Maslow bahwa aktualisasi diri adalah proses pemanusiaan penuh. Pendidikan pada dasarnya adalah mengembangkan motivasi. Dalam proses pendidikan, indikator keberhasilan pada metode pembelajaran adalah peserta didik antusias terhadap pelajaran, gembira, terjadinya perubahan berpikir dan sikap atas kemauan peserta didik sendiri. Pembelajaran seperti ini oleh Carl Rogers disebutnya sebagai teori yang bersifat humanistik. Carl R. Rogers merupakan psikolog Amerika yang juga ahli pendidikan, lahir

\footnotetext{
${ }^{6}$ M. Satrapratedja, SJ. Pendidikan sebagai Humanisasi, 24
} 
8 Januari 1902 di Oak Park, Illionis Chicago. Menurut Rogers proses belajar adalah upaya membantu siswa agar sangggup mewujudkan dirinya (self realization) sesuai dengan kemampuan dasar dan keunikan yang dimiliki anak. Kebermaknaan belajar (significant learning) sangat berpengaruh terhadap proses belajar. Belajar yang signifikan apabila belajar dirasakan relevan pada kebutuhan siswa. Selain itu juga Rogers mengemukakan bahwa setiap manusia mempunyai potensi belajar secara alami. Oleh karena itu maka keinginan untuk belajar (the desire to learn) dapat dilihat dari keingintahuan anak ketika memiliki keinginan menjelajahi lingkungan dan berusaha menemukan dan memahami pengetahuan dari pengalamannya.

Proses belajar harus berorientasi pada siswa (student centered) karena proses belajar terjadi secara abstrak dan hanya dapat dinamai jika terdapat perubahan perilaku siswa yang berbeda dengan perilaku sebelumnya. Perubahan tersebut bisa terlihat melalui perubahan pengetahuan, afektif, maupun psikomotor. Proses pembelajaran menurut Rogers bahwa guru harus mementingkan prinsip pendidikan dan pembelajaran yakni: Menjadi manusia berarti memiliki kekuatan yang wajar untuk belajar. Siswa tidak harus belajar tentang halhal yang tidak ada artinya. Siswa akan mempelajari hal-hal yang bermakna bagi dirinya. Pengorganisasian bahan dan ide baru sebagai bagian yang bermakna bagi siswa. Pengorganisasian bahan pengajaran berarti mengorganisasikan bahan dan ide baru sebagai bagian yang bermakna bagi siswa. Belajar yang bermakna dalam masyarakat modern berarti belajar tentang proses.

Sedangkan prinsip-prnsip belajar humanistik menurut Rogers Teori Belajar Humanistik meliputi: Manusia mempunyai kemampuan belajar ssecara alami; Belajar yang signifikan; Perubahan dan ancaman belajar; Tugas-tugas belajar akan mudah apabla ancaman eksternal sedikit; Belajar tanpa ancaman; Belajar bermakna apabila siswa melakukan; Patisipasi siswa dalam belajar; Belajar inisiatif sendiri; Kritik dan evaluasi diri Keterbukaan dalam belajar. ${ }^{7}$

Teori humanisme Rogers lebih penuh harapan dan menentang teori behaviorisme yang menganggap manusia sebagai robot. Menurut Rogers manusia memiliki potensi untuk maju. Manusia memiliki kecenderungan untuk aktualisasi diri karena manusia bergerak maju untuk kesempurnaan atau potensinya. Tiap individu memiliki kemampuan kreatif untuk menyelesaikan masalahnya. Dasar teori humanisme ini adalah doktrin, sikap, cara hidup yang menempatkan nilai-nilai manusia sebagai pusat dan menekankan pada kehormatan, harga diri, dan kapasitas untuk merealisasi diri untuk maksud tertentu.

Menurut Rogers yang terpenting dari pembelajaran adalah proses suasana (emotional Approach) bukan hasil dari belajar. Seorang guru harus responsif atas kebutuhan kasih sayang dalam proses pembelajaran. Perasaan gembira, tidak tertekan, nyaman itu yang diinginkan dalam proses pembelajaran. Teori humanisme Rogers banyak dipengaruhi oleh John Dewey sehingga Rogers mengemukakan bahwa dalam pembelajaran siswa diletakkan

\footnotetext{
${ }^{7}$ http://triman20.multiply.com/journal/
} 
pada bagian yang paling aktif yang disebut dengan learning by doing. Seperti halnya Dewey juga menggunakan teori ini bahwa belajar sebaiknya dilakukan dengan perbuatan langsung. Siswa aktif baik secara individual maupun komunal (kelompok) dengan melibatkan emosional, penghayatan, dan internalisasi nilai-nilai. Pada kegiatan pembelajaran learning by doing peserta didik mendapatkan pengalaman belajar, karena siswa bukan sekadar menghafalkan pelajaran namun proses pembelajaran yang melibatkan fisik dan psikis seseorang dalam sebuah tindakan atau perilaku yang kompleks yang dialami sendiri oleh siswa yang bersumber dari lingkungannya.

Para ahli psikologi pendidikan menyatakan bahwa pada hakikatnya pendidikan humanisik bukanlah strategi belajar melainkan filosofi belajar yang menitikberatkan pada keunikan yang dimiliki anak, karena pada dasarnya anak mempunyai cara sendiri dalam mengkonstruksi pengetahuan yang dipelajarinya. Baharuddin mengutip John P. Miller mengemukakan bahwa pendidikan hhumanistik memandang proses belajar bukanlah sarana transformasi pengetahuan saja namun lebih dari pada itu bahwa belajar merupakan bagian dari pengembangan nilai-nilai kemanusiaan. Miller menggagas model pendidikan yang menekankan pada humanizing classroom yang berfokus pada pengembangan model pendidikan afektif, pendidikan kepribadian dan pendidikan nilai (2005: 202).

Demikian halnya dengan Maslow tentang teori kebutuhan dasar manusia bahwa ketika siswa merasa nyaman dan aman tanpa ancaman dalam proses pembelajaran maka materi yang disampaikan akan mudah dicerna oleh siswa. ${ }^{8}$ Prinsip-prinsip yang harus diperhatikan pendidik sebelum melakukan proses pembelajaran antara lain: Berpusat pada peserta didik artinya guru harus memperhatikan perbedaan minat dan perhatian dari peserta didik perbedaan cara belajar, dan perbedaan kecerdasan. Belajar dengan melakukan. Psikolog berpandangan setiap peserta didik hanya belajar 10\% dari yang dibaca, $20 \%$ dari yang didengar, 30\% dari yang dilihat, 50\% dari yang dilihat dan didengar, dan $70 \%$ dari yang dikatakan serta $90 \%$ dari yang dikatakan dan dilakukan siswa.

Mengembangkan kemampuan sosial.

Mengembangkan keingintahuan

Mengembangkan fitrah bertuhan

Mengembangkan keterampilan pemecahan masalah.

Mengembangkan kreatifitas peserta didik.

Mengembangkan kemampuan kemampuan menggunakan ilmu dan teknologi.

Menumbuhkan kesadaran sebagai warga negara yang baik

Belajar sepanjang hayat.

Perpaduan kompetensi, kerja sama dan solidaritas.

Belajar melalui peniruan.

Belajar melalui pembiasaan.

\footnotetext{
${ }^{8}$ Henryk Misiak, et. al. Psikologi Fenomenologi, Eksisensial, dan Humanistik (Bandung: PT. Rafika Aditama, 2005), 128
} 
Pendidik memberikan motivasi dalam menemukan makna belajar, sehingga pendidik haruslah membantu peserta didik mendapatkan apa yang diinginkan dalam proses pembelajaran. Tujuan belajar berdasarkan proses belajar daripada hasil belajar. Oleh karena itu, maka proses belajar yang harus dilalui anak meliputi:

Merumuskan tujuan belajar yang jelas; Mengusahakan partisipasi aktif pembelajar melalui kontrak belajar yang bersifat jelas, jujur, dan positif; Mendorong pembelajar untuk mengembangkan kesanggupan untuk belajar atas inisiatif sendiri; Mendorong pembelajar untuk peka berpikir kritis, memaknai proses pembelajaran secara mandiri; Pembelajar didorong untuk bebas mengemukakan pendapat, memilih pilihannya sendiri, melakukan apa yang diinginkan dan menanggung risiko perilaku yang ditunjukkan; Pendidik menerima pembelajar apa adanya, berusaha memahami jalan pikiran, tidak menilai secara normatif tetapi mendorong untuk bertanggungjawab atas segala risiko belajarnya; Memberikan kesempatan pembelajar untuk maju sesuai dengan kecepatannya; Evaluasi diberikan secara individual berdasarkan perolehan prestasi pembelajar.'

Pembelajaran dengan penerapan teori humanstik dapat diaplikasikan pada materi-materi pembelajaran yang bersifat pembentukan kepribadian, hati nurani, perubahan sikap, analisis terhadap fenomena sosial. Proses belajar humanistik menekankan pada kemampuan manusia sepenuhnya.

George R. Knight mengutip Holt mengenai pandangan humanistik tentang hakikat watak dasar manusia yang dihubungkan dengan belajar bahwa anak-anak pada dasarnya pintar, energik, ingin tahu, besar kemauan untuk belajar, dan baik dalam belajar. Mereka tidak perlu disuap atau digertak untuk belajar. Mereka akan belajar dengan baik, aktif ketika senang dengan apa yang telah mereka lakukan namun ketika mereka bosan, takut, diancam, cemas, dihina maka mereka kurang baik dalam belajar. Sodiq A. Kuntoro, 2008 dalam Skesta Pendidikan Humanis Relegius mengemukakan bahwa pendidikan humanis relegius mengandung dua konsep pendidikan yang ingin diintergrasikan yaitu pendidikan humanis dan pendidikan relegius. Pengintegrasian dua konsep pendidikan ini dengan tujuan untuk dapat membangun sistem pendidikan yang dapat mengintegrasikan dari keduanya atau mengurangi kelemahannya.

Pendidikan humanis menekankan aspek kemerdekaan individu diintegrasikan dengan pendidikan relegius agar dapat membangun kehidupan individu (sosial) yang memiliki kemerdekaan tetapi tidak meninggalkan (sekuler) dan nilai-nilai keagamaan yang diikuti masyarakatnya atau menolak nilai Tuhanan (ateisme). Berikut hasil analisis penliti terhadap bangunan pemikiran yang telah dibentangkan secara populis dan akademis, yang akan menolong memahami kajian dalam penelitian ini. Dengan konstruksi di bawah ini peneliti membawa para aktivis pendidikan khusus pendidikan keagamaan (kristiani) lebih memperbanyak referensi kajian yang terbaru sehingga dapat membantu dalam menjalankan tugas mulianya.

\footnotetext{
${ }^{9}$ Trimanjuiarso, Journal Teori Belajar Humanistik
} 


\section{Kesimpulan}

Bagi peneliti pembentukkan karakter merupakan hal yang sangat substansial oleh karena karakter bangsa akan sangat ditentukan oleh karakter rakyatnya dikemudian hari. Maka dari itu mulai dari dini anak-anak semestinya mendulang pendidikan yang berbasis pembentukkan karakter bukan hanya pada aspek kognitif, artinya hanya menanamkan nilai-nilai melalui pengetahuan intelektual semata-mata. Tapi juga ada aspek afektif yang menekankan rasa yang dapat mengubah diri anak secara psikologis kemudian aspek psikomotorik yang mengedepankan anak untuk melakukan cara-cara positif sebagai bagian karakter diri.

Hal tersebut belum cukup bila hanya disampaikan secara verbal dan non verbal akan tetapi diperlukan pendekatan yang populis dengan mengkolaborasikan pendidikan humanis-religius, artinya penekanan dan penanaman nilai serta norma disematkan secara humanis tidak secara frontal. Hal tersebut dibutuhkan oleh karena masyarakat saat ini banyak sekali disajikan tontonan yang kurang manusiawi, teringat beberapa waktu yang lalu tawuran anak sekolah sehingga mengakibatkan hilangnya nyawa anak. Kemudian pendidikan religius merupakan penanaman nilai-nilai agamis yang dikemas sedemikian rupa sehingga mampu menyajikan teladan yang kontekstual dan relevan pada era milenium. Karena dalam pendidikan religius khususnya kekristenan mampu memberikan kaidah-kaidah bermanfaat dalam pembentukkan karakter anak dengan berbagai pemikiran moderen yang telah merekonstruksi ajaran agama khususnya Kristen.

Jadi singkatnya peneliti menyimpulkan pada riset ditemukan fakta (fact finding) bahwasanya pendidikan humanis-religius dalam rangka pembentukkan karakter anak baru pada tahap parsial, artinya pendekatan yang digunakan oleh kebanyakkan pendidik hanya pendidikan religius secara jelas menekankan akhlak dan nilai-nilai agamis. Akan tetapi pendekatan melalui pendidikan humanis belum secara realitas terlihat karena hal itu cukup asing dan perlu pemahaman lebih dalam lagi. Maka dari itu peneliti ingin menegaskan sekali lagi bahwa pendidikan humanis-religius dalam pembentukkan karakter anak khususnya pada era milenium merupakan hal yang signifikan dalam menaruh nilai-nilai, sikap-sikap dan tingkah laku serta tutur kata. Hal itu akan merangkai dalam karakter yang akan dibentuk melalui konstruksi pendidikan humanis-religius.

\section{Referensi}

Alkitab. 2005. Lembaga Alkitab Indonesia (LAI). Jakarta.

A, Koesoema Doni. 2010. Pendidikan Karakter. Strategi Mendidik Anak di Zaman Global. Cetakan Kedua. Jakarta: Grasindo.

Aqib, Zainal. 2012. Pendidikan Karakter di Sekolah. Membangun Karakter dan Kepribadian Anak. Bandung: Yrama Widya.

Baharuddin dan Moh Makin. (2005). Pendidikan humanistik (konsep, Teori dan Aplikasi Praksis dalam Dunia Pendidikan ). Yogyakarta:Ar-Ruz Media.

Creswell. J. W. (1994). Research Design Qualitantive \& Quantitative Approaches. London. New Delhi: Sage. 
Denzin. N. K. \& Lincoln. Y. S. (Editors) (1994). Handbook of Qualitative Research. London. New Delhi: Sage.

Fauzi, Ibrahim Ali. Postmodernisme Vis a Vis Modernisme, dalam Postmodernisme dan Masa Depan Peradaban.

Gutek, Gerald L. 1988. Philosophical and Ideological Perspective on Education. Prentice Hall. Englewood.

Henryk Misiak an Virginia Staudt Sexton. (2005). Psikologi Fenomenologi, Eksisensial, dan Humanistik. Bandung: PT. Rafika Aditama

Hidayat, Ainur Rahman. 2006. Implikasi Postmodernisme Dalam Pendidikan. Tadrîs Volume 1. Nomor 1.

J.R, Adisusilo Sutarjo. 2013. Pembelajaran Nilai Karakter. Konstruktivisme dan VCT sebagai Inovasi Pendekatan Pembelajaran Afektif. Jakarta: PT Raja Grafindo Persada.

Kaelan. 2005. Metode Penelitian Kualitatif Bidang Filsafat. Yogyakarta: Pardigma

Maksum, Ali \& Ruhendi, Luluk Yunan. 2004 Paradigma Pendidikan Universal di Era Modern dan Postmodern, IRCiSoD. Yogyakarta.

Moleong. L. J. 2001. Metodologi Penelitian Kualitatif (Cetakan Keempat Belas). Bandung: PT. Remaja Rosdakarya.

Mursell, James L. 1975. Succesfull Teaching. New York: The McGraw_Hill Book Company.Inc.

Palmer, Joy A. (2003). Fifty Modern Tingkers On Education. Diindonesiakan Farid Assifa. Yogyakarta: Ircisod.

Piliang, Yasraf Amir. 1999. Hiper-Realitas Kebudayaan. Yogyakarta: LKiS.

Pujiriyanto. Membangun Jati diri Bangsa dan Rasa Percaya Diri Bangsa Melalui Pendidikan Profetik. Makalah, tanpa tahun.

Ritzer, George. 2003. Teorisosial Postmodern.Diterjemahkan oleh Muhammad Taufik, Yogyakarta: Juxtapose.

Rogers, R. Carld. 1987. Antara Engkau dan Aku. Diindonesiakan Agus Cremers. Jakarta: PT. Gramedia.

Sadullah, Uyoh. 2003. Pengantar Filsafat Pendidikan. Bandung: CV Alvabeta. 2003.

Saptono. 2011. Dimensi-Dimensi Pendidikan Karakter. Wawasan, Strategi, dan Langkah Praktis. Jakarta: Esensi Erlangga Group.

Smith, Samuel, Barnes \& Noble Books. 1986. Ideas Of The Great Educators. Diindonesiakan Gagasan-Gagasan Besar Tokoh-tokoh dalam Bidang Pendidikan. Bumi Aksara.

Strauss. A. \& Corbin. J. (1990). Qualitative Analysis For Social Scientists. New York: Cambridge University Press.

Satrapratedja, M. SJ.2001. Pendidikan sebagai Humanisasi. Yogyakarta: Universitas Sanata Dharma.

Sastrapratedja, M. 2012. Humanisme sebagai Prinsip Pendidikan menurut Driyarkara. Makalah Ilmiah. Disampaikan dalam Konggres Pendidikan, Pengajaran, dan Kebudayaan Tahun 2012, balai Senat UGM, 7-8 Mei 2012

Strauss. A. \& Corbin. J. (1990). Qualitative Analysis For Social Scientists. New York: Cambridge University Press.

Sutrisno, Mudji. Postmodernisme, Tantangan bagi Ilmu Pengetahuan, dalam Postmodernisme dan Masa depan Peradaban.

Undang-Undang Nomor 20 Tahun 2003 Tentang Sistem Pendidikan Nasional. 
http://pergerakan07.blogspot.com/2012/03/postmodernisme-dan-implikasinya-dalam.html diunduh pada tanggal 20 November 2013.

http://triman20 .multiply.com/journal/ Teori Belajar Humanistik

www.goodreads.com Pendidikan karakter. 